\title{
ІІляхи оптимізації лазерної та хімічної абляції вен при варикозній хворобі з коморбідним цукровим діабетом
}

\begin{abstract}
Мета роботи: оцінити ефективність ендоваскулярної лазерної та хімічної абляції вен при варикозній хворобі (ВХ) із коморбідним цукровим діабетом (ЦД) типу 2, розробити найбільш оптимальну технологію лікувальних заходів у такої категорії хворих. Матеріали і методи. Під наглядом перебували 162 хворих на ВХ (19 \% чоловіків і 81 \% жінок із середнім віком 50 років), серед яких співвідношення II, III, IV, V i VI класів венозної недостатності склало 1:1:3:1:2. ЦД мав місце в 14 \% випадків, при цьому розподіл легкої, середньої тяжкості та тяжкої форми хвороби склав 1:2:4, а фаз компенсації, субкомпенсації й декомпенсації - 1:4:6. У крові з ліктьової вени і ураженої вени нижніх кінцівок вивчено вміст показників глюкози, глікованого гемоглобіну, інсуліну, С-пептиду, фруктозаміну та асоційованих із вуглеводним метаболізмом мікроелементів (хрому, марганцю, селену, цинку). Лазерну абляцію вен здійснювали за допомогою апарата “Фотоніка-Ліка-Хірург” (Україна) і виконання паравазальної “подушки” розчином Кляйна за допомогою помпи для тумесцентної анестезії під ультразвуковим контролем, а хімічну (склеротерапію) - розчином склеровейну або фібровейну. Перший метод виконаний 63 (39\%) хворим, другий - 99 (61 \%).

Результати досліджень та їх обговорення. Ефективність лазерної абляції залежить від класу венозної недостатності, перенесеного у минулому флеботромбозу, додаткового використання в комплексі лікувальних заходів ривароксабану та низькомолекулярних гепаринів, методики лазерної коагуляції, що проводиться, наявності й тяжкості перебігу коморбідного ЦД показників вуглеводного обміну в цільовій вені, причому після хірургічного втручання зростають параметри селен- і цинкемії, а число виниклих ускладнень залежить від фази ЦД та рівня хрому в крові з варикозно розширеної вени. Результати склеротерапії у жінок були кращі, а число ускладнень менше, які залежали від рівня венозної недостатності, перенесеного у минулому флеботромбозу і просвіту цільової вени гомілки, параметрів у крові з неї інсуліну, С-пептиду й фруктозаміну. При порівняльній оцінці різних методів хірургічного лікування ВХ, лазерна аблація (коагуляція) відрізнялася більшою тяжкістю перебігу коморбідного ЦД, частішим додатковим використанням ривароксабану і цикло-3-форту, виключенням із розробки хворих із діабетичною енцефалопатією, а склеротерапія не була використана у пацієнтів з нефропатією, при цьому ефективність виконаних заходів в обох групах виявилася приблизно однаковою. У хворих на ВХ розроблено лікувальний алгоритм застосування найбільш оптимальної медичної технології лазерної і хімічної аблації з урахуванням характеру перебігу венозної патології та коморбідного ЦД, системних й локальних змін вуглеводного метаболізму, фонової медикаментозної терапії.
\end{abstract}

Ключові слова: вени; варикоз; цукровий діабет; лікування; абляція судин.

Постановка проблеми і аналіз останніх досліджень та публікацій. Варикозна хвороба (ВХ) $є$ найбільш актуальною проблемою судинної хірургії $[1,2]$, особливо у пацієнтів із наявністю коморбідних станів [3, 20]. На хронічну венозну недостатність нижніх кінцівок страждає 1/3-1/2 частини дорослого населення $[4,5]$, що завдає величезної економічної та медико-соціальної шкоди не лише пацієнтам, а й державам в цілому [6, 7]. Чинником ризику виникнення, несприятливого перебігу i низької ефективності лікування ВХ $€$ коморбідний цукровий діабет 2-го типу (ЦД) [8, 9], який істотно погіршує якість життя таких людей $[10,11]$.

До хірургічних методів лікування ВX належать ендовазальна (ендоваскулярна, ендовенозна) лазерна та хімічна абляції уражених вен (ЕВЛА, ЕВХА), які часто-густо об'єднуються поняттям “інтервенційна терапія” $[1,12]$. Гіпотетично надалі збільшуватиметься частота використання ЕВЛА і ЕВХА [13], оскільки наявна їх досить висока ефективність, відносно невелике число ускладнень та швидке відновлення повсякденного життя хворих в ранньому післяопераційному періоді [14]. Вказують на більш високу ефективність лікування хворих на ВХ шляхом ЕВХА порівняно з ЕВЛА [15, 16], однак існують й діаметрально протилежні відомості $[17,18]$. Необхідно зазначити, що ефективність лікування хворих на ВX із коморбідним ЦД вивчено недостатньо, потрібна оптимізація методів ЕВЛА і EBXA [19].

Мета роботи: оцінити ефективність ендоваскулярної лазерної та хімічної абяції вен при ВХ 3 коморбідним ЦД типу 2, розробити найбільш оптимальну технологію лікувальних заходів у такої категорії хворих.

Матеріали і методи. Проведено аналіз спостереження за 162 пацієнтами з ВБ у віці від 31 до 72 років (в середньому $(49,5 \pm 0,61)$ року). Серед цих хворих було 19,1 \% чоловіків і 80,9 \% жінок, відповідно у віці $(56,6 \pm 1,68)$ року і $(47,8 \pm 0,55)$ року $(\mathrm{t}=6,27, \mathrm{p}<0,001)$. За класифікацією CEAP (Clinical Etiology Anatomy Pathophysiology) виразний тип венозної недостатності (С4-С6) встановлено в 72,6 \% 
випадків. Середній діаметр стовбура цільової вени дорівнював $(6,4 \pm 0,16)$ мм, причому, в групі чоловіків він виявився вірогідно (на $32 \%$ ) більшим ( $\mathrm{t}=5,01$, $\mathrm{p}<0,001) .12,4$ \% від числа обстежених хворих на BX перенесли флеботромбоз, 13,0 \% мали пригирлеве розширення вени, 9,3 \% - нерівний хід венозного стовбура. В цілому, тяжкість перебігу ВХ у чоловіків була більшою, а С5-С6 класи венозної недостатності відзначено в 3,3 раза частіше, при цьому C2-С3-класи були відсутні $\left(\mathrm{X}^{2}=349,45, \mathrm{p}<0,001\right)$.

Хворим виконували ультразвукову доплерографію судин (“Aplia-XG-Toshiba”, Японія i “SonoScape-S6”, Китай). Досліджували основні біомаркери ЦД - рівні глюкози (Gl), інсуліну (INS), глікольованого гемоглобіну (HbA1/c), С-пептиду (CP) та фруктозаміну (FA), а також діабетасоційованих мікроелементів (ME), які беруть участь і в патогенетичних побудовах ВX - хрому (Cr), марганцю (Mn), селену (Se) й цинку (Zn). Показники INS, CP, FA і ME оцінювали одночасно в сироватці крові з ліктьової вени () ( ) з ураженої вени гомілок (). Підраховували тяжкість інсулінорезистентності HOMA (Homeostatic Model Assessment). Для визначення рівнів ME застосовували електрографітовий атомізатор “SolAAr-Mk2-MOZe” (Велика Британія), для Gl, CP і FA - біохімічні аналізатори “Olympus-AU-640” (Японія) і “BS200” (Китай), а також спектрофотометр “СФ46” (Росія). Визначення концентрації INS у крові проводили імуноферментним методом (рідер "PR2100 Sanofi diagnostic pasteur”, Франція), показник НbА1/с оцінювали методом високої рідинної хроматографії на аналізатоpi “BIO-RAD-D10” (США).

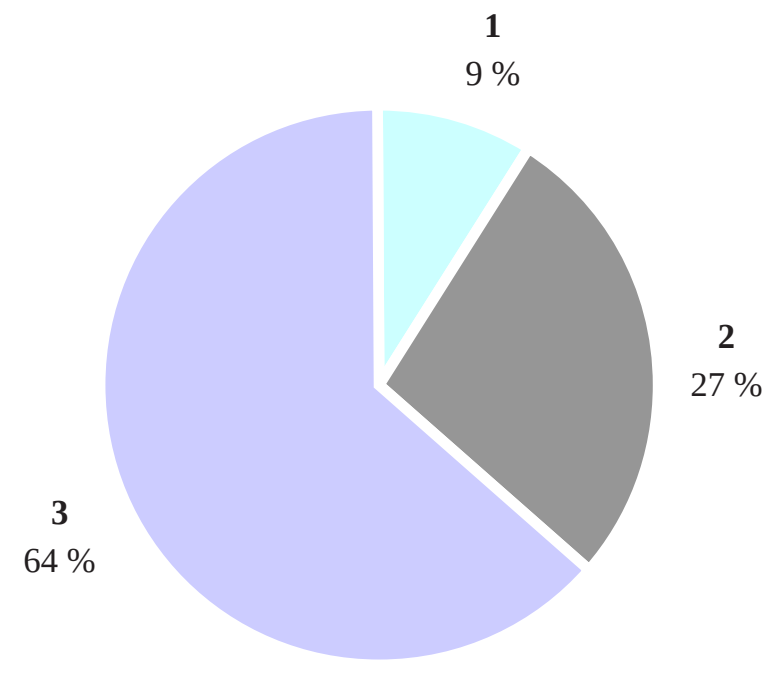

ЕВЛА
Статистичну обробку отриманих результатів виконано за допомогою комп’ютерного варіаційного, непараметричного, кореляційного, одно- (ANOVA) і багатофакторного (ANOVA/ MANOVA) дисперсійного аналізу (програми “Microsoft Excel” та "Statistica-Stat-Soft”, США). Оцінювали середні значення, їх стандартні похибки й відхилення, коефіцієнти непараметричної кореляції Кендалла, критерії однорідності дисперсії Брауна-Форсайта і багатофакторного аналізу Уїлкоксона-Рао, відмінностей Стьюдента (t) і Макнемара-Фішера $\left(\chi^{2}\right)$, достовірність статистичних показників (р). Підраховували прогностично позитивний результат моделі (PPV).

Результати досліджень та їх обговорення. 63 (38,9 \%) хворим на ВХ виконано ЕВЛА, 99 (61,1 \%) - ЕВХА. У 17,5 \% від числа пацієнтів з ЕВЛА і у 12,1 \% з ЕВХА діагностували коморбідний ЦД 2-го типу. Якщо в 1-й групі співвідношення легкої, середньої тяжкості і тяжкої форми ЦД склало 1:3:7, то у 2-й групі - 1:2:3 ( $\mathrm{X}^{2}=8,24$, $\mathrm{p}=0,016)$, а фази компенсації, субкомпенсації і декомпенсації - відповідно 1:2:8 та 1:6:5 ( $x^{2}=43,35$, $\mathrm{p}<0,001)$. Таким чином (рис. 1,2$)$, лазерну абляцію виконували хворим із більш виразним перебігом коморбідного ЦД. ЕВЛА не проводили у випадках наявності діабетичної енцефалопатії, а EBXА - у хворих на ЦД з діабетичною нефропатією $\left(x^{2}=5,86, p=0,016\right.$ i $\left.\chi^{2}=3,76, p=0,052\right)$. ЕВЛА здійснювали в 2,6 раза частіше на тлі призначення ривароксабану $\left(\mathrm{x}^{2}=4,16, \mathrm{p}=0,041\right)$ і на $34 \%$ цикло3-форту $\left(x^{2}=7,12, p=0,008\right)$.

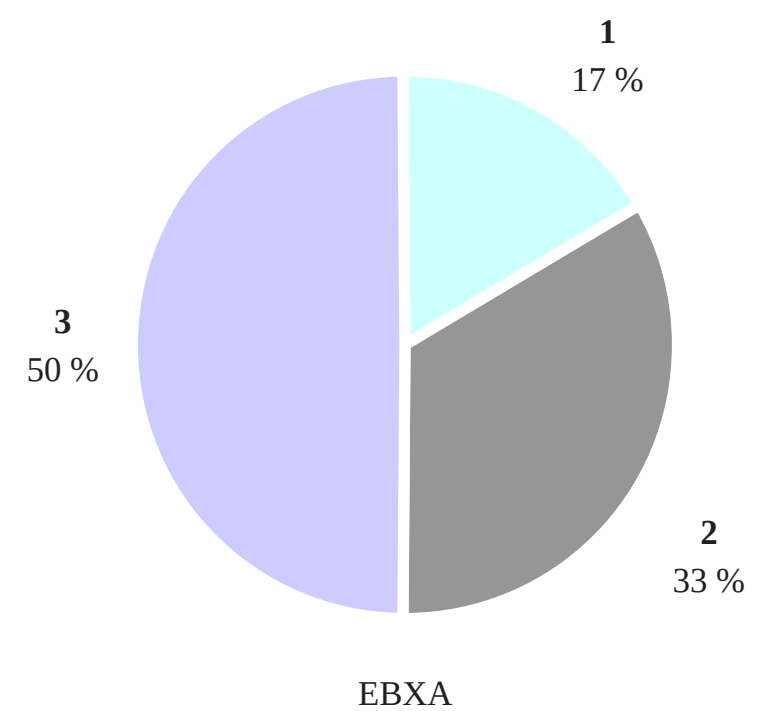

Рис. 1. Тяжкість перебігу ЦД у балах $\left(\chi^{2}=8,24, \mathrm{p}=0,016\right)$. 


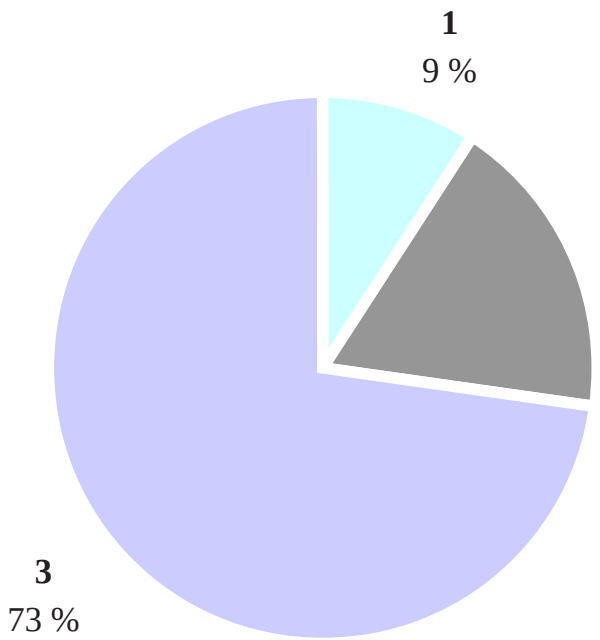

ЕВЛА

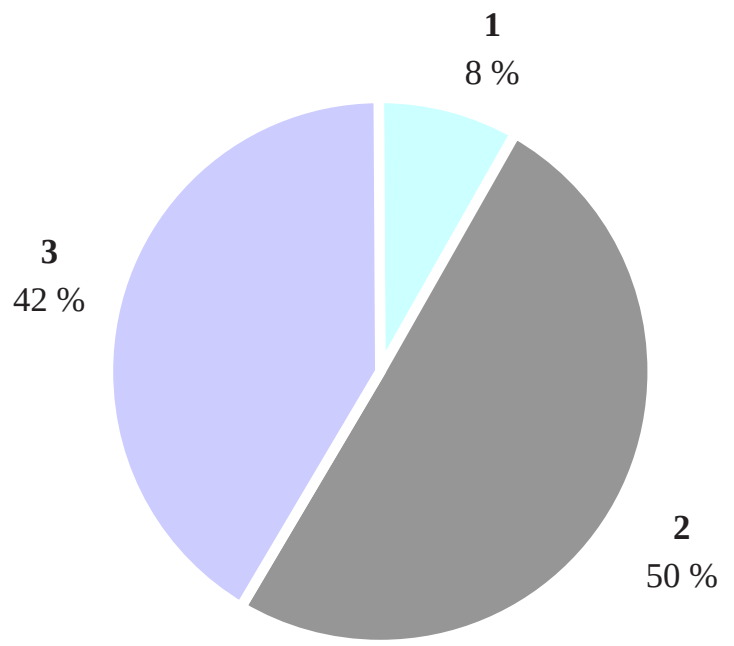

EBXA

Рис. 2. Фаза ЦД $\left(^{2}=43,35, \mathrm{p}<0,001\right)$. Відмінності частоти розподілу хворих на ВX з коморбідним ЦД при різних методах абляції уражених вен.

ЕВЛА здійснювали за допомогою вітчизняного апарата “Фотоніка-Ліка-Хірург” (використовували лазер із довжиною хвилі $\lambda=1470$ нм) і виконанням паравазальної “подушки” розчином Кляйна за допомогою помпи для тумесцентної анестезії під ультразвуковим контролем. Всього ЕВЛА здійснювали перманентно на 56 нижніх кінцівках. При середньому діаметрі цільової вени $(6,6 \pm 0,29)$ мм використовували такі фізичні параметри лазерної абляції: довжина стрипінгу - $(27,9 \pm 0,81)$ см, потужність лазерного випромінювання - $(10,8 \pm 0,34)$ Вт, сумарна енергія лазерного лікування - $(1,4 \pm 0,05)$ кДж, енергія випромінювання на довжину стрипінгу - $(51,7 \pm 1,64)$ Дж, енергія випромінювання на площу інтими $(27,5 \pm 1,29)$ Дж/см². Всім хворим ЕВЛА виконували під місцевою анестезією (лідокаїн+адреналін+сода). У 3/4 від числа хворих використовували тумесцентний тип світловоду, а у $1 \frac{1}{4}$ застосовували радіальний тип. Склеротерапію при ЕВХА виконували уведенням склеровейну або фібровейну.

Фонова медикаментозна терапія складалася 3 препаратів діосміну (детралекс, флебодіа), гелю ліотромба-1000, антиагреганту клопідогрелю (лістабу), при флеботромбозах використовували ривароксабан i/або низькомолекулярні гепарини (цібор, клексан), а у випадках хронічної лімфовенозної недостатності - цикло-3-форт. Призначене раніше гіпоглікемічне лікування ЦД метформіном, піоглітазоном, глімепіридом, інсуліном (тресибою, віктозою) хворі продовжували отримувати після оперативного лікування на тлі засобів патогенетичної медикаментозної терапії ВX.
ВХ навіть без ЦД супроводжується змінами вуглеводного обміну, що має гендерні особливості, вірогідно пов'язане з тяжкістю перебігу і клінічними проявами коморбідного ЦД, місцевою продукцією FA ураженої веною, при цьому визначаються ступенем тяжкості венозної недостатності, залежать від стану варикозної вени (просвіт стовбура, перенесений флеботромбоз), що демонструють дисперсійний і кореляційний аналіз. Серед ME, пов'язаних з метаболізмом вуглеводів, ВХ характеризується гіпоцинкемією (більшою мірою у чоловіків), що супроводжується більш низькими рівнями в крові з варикозно розширеної вени $\mathrm{Cr}$, Se й Zn, корелюючи з показниками вуглеводного обміну (INS, CP, FA), залежить від тяжкості BX (Cr, Zn).

За даними критеріїв Брауна-Форсайта і Кендалла, ефективність ЕВЛА пов'язана з класом венозної недостатності, перенесеним у минулому флеботромбозом, додатковим використанням у комплексі лікувальних заходів рівароксабану й гепаринів, методики проведеної лазерної коагуляції, наявності та тяжкості перебігу коморбідного ЦД, показників вуглеводного обміну в цільовій вені, причому після малоінвазивного хірургічного втручання зростають параметри селенемії й цинкемії, а число виниклих ускладнень залежить від фази ЦД та рівня $\mathrm{Cr}$ в крові з варикозно розширеної вени. Результати ЕВХА у жінок краще, число ускладнень менше, що залежить від рівня венозної недостатності, перенесеного в минулому флеботромбозу та просвіту цільової вени гомілки, параметрів у крові з неї INS, CP і FA, а із ліктьової 
вени - асоційованих з вуглеводним метаболізмом ME, при цьому склеротерапія викликає вірогідне підвищення рівнів Cr, Se i Zn.

Ефективність лікування і за 1 місяць після ЕВЛА та ЕВХА і через 6 місяців виявилася приблизно однаковою. В цілому, поліпшення й значне поліпшення через 1 місяць після ЕВЛА констатовано, відповідно, в 49,2 \% та 41,3 \% випадків, за 6 місяців - у 14,3 \% і 85,7 \%, тоді як після EBXА - в 53,5 \% і 36,4 \% та 14,1 \% і 85,9 \%. При оцінці ефективності лікування використовували наступну градацію: під “значним поліпшенням” розуміли зникнення скарг хворих, зменшення діаметра цільової вени за 1 місяць на 10 \% і більше, а через 6 місяців - формування повної оклюзії судини на тлі будь-яких проявів ускладнень лікування. Обов’язковою умовою “поліпшення” було зменшення ступеня венозної недостатності й створення сегментарної оклюзії, звичайно, при обов’язковій відсутності проявів рецидиву патологічного процесу.

У контексті розробки алгоритму найбільш раціонального застосування ЕВЛА і ЕВХА у хворих на ВX з коморбідним ЦД (рис. 3) ми враховували вихідні рівні параметрів вуглеводного метаболізму (INS, Gl, HbA1/c, HOMA, CP, FA) і показники асоційованих із ним ME (Cr, Mn, Se, Zn), причому в крові з ліктьових вен і варикозних вен гомілок. Встановлено, що при ЕВЛА прогнозпозитивним чинником $є$ початковий вміст у крові з ураженої вени Zn>7 мг/л, а прогнознегативними - рівні HbA1/ c $>12 \%$ і співвідношення $\mathrm{Cr}_{1 / s}>130 \%$, тоді як ЕВХА не показано хворим у випадках перенесеного флеботромбозу й концентрації в периферійній крові Mn>33 мкг/л. При гіперглікемії понад 12 ммоль/л методом вибору лікування ВХ є ЕВХА.

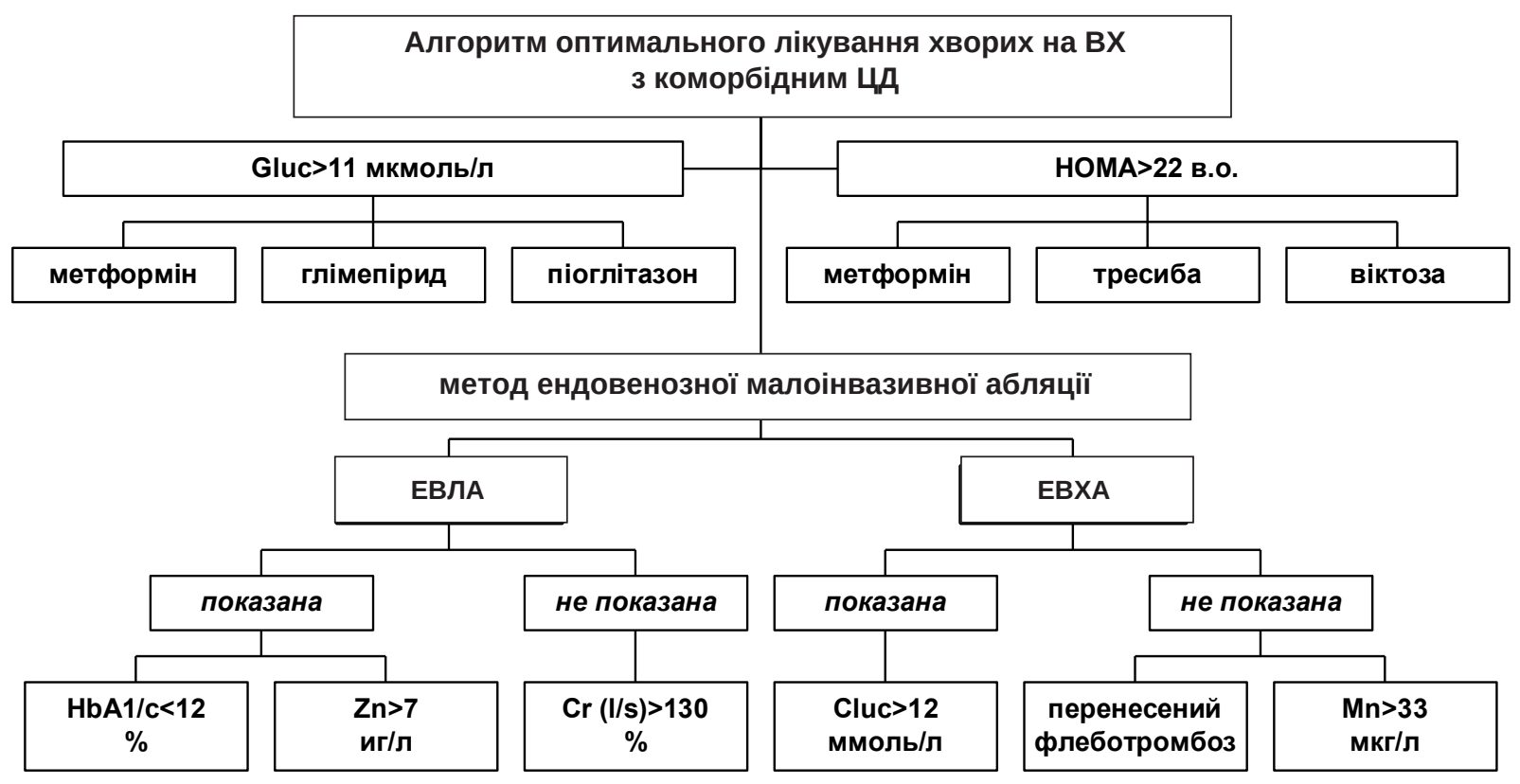

Рис. 3. Алгоритм оптимальної абляції уражених судин при ВX із коморбідним ЦД.

3 урахуванням поданих даних, які базувалися на варіаційному, дисперсійному та кореляційному аналізі результатів досліджень з підрахунком $\mathrm{PPV}$, ми ретроспективно розподілили хворих на групу з раціональним лікуванням і нераціональним (виявилось у співвідношенні 1:4). Оптимальний підхід до лікування (41 пацієнт) дозволив досягти значного поліпшення через 1 місяць після виконаної абляції ураженої вени в 3,6 раза частіше $\left(\mathrm{x}^{2}=46,33, \mathrm{p}<0,001\right)$, а через 6 місяців - на $15 \%$ $\left(x^{2}=3,91, p=0,048\right)$, більшою мірою (на $\left.1 / 4\right)$ вдалося зменшити просвіт цільової вени $(\mathrm{t}=2,10, \mathrm{p}=0,038)$, на 3/4 частіше отримати повну оклюзію судини $\left(x^{2}=23,58, p<0,001\right)$, у всіх випадках уникнути ускладнень (флебіт, тромбоз глибоких вен, гематоми, гіперпігментація шкіри, парестезії), яких на тлі нераціонального підходу до лікування відзначено в $19,0 \%$ випадків $\left(x^{2}=9,08, \mathrm{p}=0,003\right)$.

Висновки. 1. При порівняльній оцінці різних методів малоінвазивного хірургічного лікування $\mathrm{BX}$, лазерна, порівняно з хімічною абляцією вен, відрізнялася більш тяжким перебігом коморбідного ЦД, частим додатковим використанням ри- 
вароксабану й цикло-3-форту, на тлі виключення з розробки хворих з діабетичною енцефалопатією (склеротерапію не застосовували в пацієнтів із діабетичною нефропатією).

2. Ефективність ЕВЛА і ЕВХА у хворих на ВХ через 1 та 6 місяців після оперативного втручання виявилася приблизно однаковою.

3. Медична технологія використання ЕВЛА і EBXА при ВX повинна враховувати характер перебігу венозної патології й коморбідного ЦД, системних та локальних змін вуглеводного метаболізму, фонової медикаментозної терапії.

4. Розроблений найбільш оптимальний лікувальний алгоритм застосування лазерної та хімічної абляції при ВХ з коморбідним ЦД дозволив ві-

\section{СПИСОК ЛІТЕРАТУРИ}

1. Youn Y. J. Chronic venous insufficiency and varicose veins of the lower extremities / Y. J. Youn, J. Lee // Korean J. Intern. Med. - 2018. - Vol. 26 (10). - P. 230. doi: 10.3904/kjim.2018.230.

2. A study on prevalence and risk factors for varicose veins in nurses at a university hospital / M. J. Yun, Y. K. Kim, D. M. Kang [et al.] // Saf. Health Work. - 2018. - Vol. 9 (1). - P. 79-83. doi: 10.1016/j.shaw.2017.08.005.

3. Clinical outcomes after varicose vein procedures in octogenarians within the vascular quality initiative varicose vein registry / D. C. Sutzko, A. T. Obi, A. S. Kimball [et al.] // J. Vasc. Surg. Venous Lymphat. Disord. - 2018. - Vol. 6 (4). - P. 464 470. doi: 10.1016/j.jvsv.2018.02.008.

4. Incidence and risk factors for venous reflux in the general population: edinburgh vein study / L. A. Robertson, C. J. Evans, A. J. Lee [et al.] // Eur. J. Vasc. Endovasc. Surg. - 2014. - Vol. 48. - P. 208-214. doi: 10.1258/phleb.2013.007061.

5. De Popas E. Varicose veins and lower extremity venous insufficiency / E. De Popas, M. Brown // Semin. Intervent. Radiol. - 2018. - Vol. 35 (1). - P. 56-61. doi: 10.1055/s-0038-1636522.

6. Factors associated with physical activity levels in people with venous leg ulcers: A multicentre, prospective, cohort study / D. Smith, V. Team, G. Barber [et al.] // Int. Wound. J. - 2018. Vol. 15 (2). - P. 291-296. doi: 10.1111/iwj.12868.

7. Systematic review and meta-analysis of endovascular and surgical revascularization for patients with chronic lower extremity venous insufficiency and varicose veins / S. Vemulapalli, K. Parikh, R. Coeytaux [et al.] // Am. Heart J. - 2018. Vol. 196 (2). - P. 131-143. doi: 10.1016/j.ahj.2017.09.017.

8. Greenhalgh D. G. Management of the skin and soft tissue in the geriatric surgical patient / D. G. Greenhalgh, // Surg. Clin. North Am. - 2015. - Vol. 95 (1). - P. 103-114. doi: 10.1016/j. suc.2014.09.008.

9. Chronic venous disease and comorbidities / P. Matic, S. Jolic, S. Tanaskovic [et al.] // Angiology. - 2015. - Vol. 66 (6). P. 539-544. doi: 10.1177/0003319714541988.

10. Emerging trends in therapeutic algorithm of chronic wound healers: recent advances in drug delivery systems, concepts-toclinical application and future prospects / M. Shao, Z. Hussain, H. E. Thu [et al.] // Crit. Rev. Ther. Drug. Carrier Syst. - 2017. Vol. 34 (5). - P. 387-452. doi: 10.1615/CritRevTherDrugCarrier Syst.2017016957. рогідно підвищити ефективність лікувальних заходів через 1 місяць після хірургічного втручання в 3,6 раза, через 6 місяців - на $15 \%$, досягти повної оклюзії цільової вени в ці терміни спостереження на 3/4 частіше, повністю уникнути післяопераційних ускладнень.

Перспективи подальших досліджень: у майбутньому розроблятиметься медична технологія фонової медикаментозної терапії хворих на ВX із коморбідним ЦД, передбачатиметься простеження віддалених результатів малоінвазивного хірургічного лікування (ЕВЛА, ЕВХА) у такої категорії хворих, виділення прогностичних критеріїв для різних оперативних втручань.
11. Overweight in rural elderly: association with health conditions and quality of life / D. M. D. S. Tavares, A. F. Bolina, F. A. Dias [et al.] // Cien. Saude Colet. - 2018. - Vol. 23 (3). - P. 913-922. doi: 10.1590/1413-81232018233.25492015.

12. Murad M. H. A systematic review and meta-analysis of the treatments of varicose veins / M. H. Murad, F. Coto-Yglesias, M. Zumaeta-Garcia // J. Vasc. Surg. - 2011. - Vol. 53 (5). P. 49-65.

13. Comparison of $1470 \mathrm{~nm}$ laser and radial 2ring fiber with $980 \mathrm{~nm}$ laser and bare-tip fiber in endovenous laser ablation of saphenous varicose veins: a multicenter, prospective, randomized, non-blind study / M. Hirokawa, T. Ogawa, H. Sugawara [et al.] // Ann. Vasc. Dis. - 2015. - Vol. 8 (4). - P. 282-289. doi: 10.3400/ avd.oa.15-00084.

14. Siribumrungwong B. A systematic review and metaanalysis of randomized controlled trials comparing endovenous ablation and surgical intervention in patients with varicose vein / B. Siribumrungwong, P. Noorit, C. Wilasrusmee // Eur. J. Vasc. Endovasc. Surg. - 2012. - Vol. 44. - P. 214-223.

15. Comparing endovenous laser ablation, foam sclerotherapy, and conventional surgery for great saphenous varicose veins / A. A. Biemans, M. Kockaert, G. P. Akkersdijk [et al.] // J. Vasc. Surg. - 2013. - Vol. 58. - P. 727-734.

16. Van der Velden S. K. Management strategies for patients with varicose veins (C2-C6): results of a worldwide survey / S. K. Van der Velden, O. Pichot, R. R. van den Bos // Eur. J. Vasc. Endovasc. Surg. - 2015. - Vol. 49. - P. 213-220.

17. Randomized clinical trial of endovenous laser ablation versus conventional surgery for small saphenous varicose veins / N. Samuel, D. Carradice, T. Wallace [et al.] // Ann. Surg. - 2013. - Vol. 257. - P. 419-426. doi: 10.1097/SLA.0b013e318275f4e4. 18. A randomized trial comparing treatments for varicose veins / J. Brittenden, S. C. Cotton, A. Elders [et al.] // N. Engl. J. Med. 2014. - Vol. 371. - P. 1218-1227. doi: 10.1056/NEJMoa1400781. 19. Kaspar S. Veins and diabetes / S. Kaspar // Vnitr. Lek. 2016. - Vol. 56 (4). - P. 329-332.

20. Планове хірургічне лікування первинного симптомного хронічного захворювання вен у вагітних / В. М. АнтонюкКисіль, І. Я. Дзюбановський, В. М. Єнікеєва [та ін.] // Актуальні питання педіатрії, акушерства та гінекології. - 2019. № 1. - C. 43-54. 


\section{REFERENCES}

1. Youn, Y.J., \& Lee, J. (2018). Chronic venous insufficiency and varicose veins of the lower extremities. Korean J. Intern. Med., 26 (10), 230. doi: 10.3904/kjim.2018.230.

2. Yun, M.J., Kim, Y.K., Kang, D.M., Kim, J.E., Ha, W.C., \& Jung, K.Y. (2018). A study on prevalence and risk factors for varicose veins in nurses at a university hospital. Saf. Health Work, 9 (1), 79-83. doi: 10.1016/j.shaw.2017.08.005.

3. Sutzko, D.C, Obi, A.T., Kimball, A.S., Smith, M.E., Wakefield, T.W., \& Osborne, N.H. (2018). Clinical outcomes after varicose vein procedures in octogenarians within the vascular quality initiative varicose vein registry. J. Vasc. Surg. Venous Lymphat. Disord., 6 (4), 464-470. doi: 10.1016/j. jvsv.2018.02.008.

4. Robertson, L.A., Evans, C.J., Lee, A.J., Allan, P.L., Ruckley, C.V., \& Fowkes, F.G. (2014). Incidence and risk factors for venous reflux in the general population: edinburgh vein study. Eur. J. Vasc. Endovasc. Surg., 48, 208-214. doi: 10.1258/ phleb.2013.007061.

5. De Popas, E., \& Brown, M. (2018). Varicose veins and lower extremity venous insufficiency. Semin. Intervent. Radiol., 35 (1), 56-61. doi: 10.1055/s-0038-1636522.

6. Smith, D., Team, V., Barber, G., O'Brien, J., Wynter, K., McGinnes, R., ..., \& Weller, C.D. (2018). Factors associated with physical activity levels in people with venous leg ulcers: A multicentre, prospective, cohort study. Int. Wound. J., 15 (2), 291296. doi: 10.1111/iwj.12868.

7. Vemulapalli, S., Parikh, K., Coeytaux, R., Hasselblad, V., McBroom, A., Johnston, A., ..., \& Sanders, G.D. (2018). Systematic review and meta-analysis of endovascular and surgical revascularization for patients with chronic lower extremity venous insufficiency and varicose veins. Am. Heart J., 196 (2), 131-143. doi: 10.1016/j.ahj.2017.09.017.

8. Greenhalgh, D.G. (2015). Management of the skin and soft tissue in the geriatric surgical patient. Surg. Clin. North Am., 95 (1), 103-114. doi: 10.1016/j.suc.2014.09.008.

9. Matic, P., Jolic, S., Tanaskovic, S., Soldatovic, I., Katsiki, N., Isenovic, E., \& Radak, Dj. (2015). Chronic venous disease and comorbidities. Angiology 66 (6):539-44. doi: 10.1177/0003319714541988.

10. Shao, M., Hussain, Z., Thu, H.E., Khan, S., de Matas, M., Silkstone, V., ..., \& Bukhari S.Na. (2017). Emerging trends in therapeutic algorithm of chronic wound healers: recent advances in drug delivery systems, concepts-to-clinical application and future prospects. Crit. Rev. Ther. Drug. Carrier Syst., 34 (5), 387452. doi: 10.1615/CritRevTherDrugCarrierSyst.2017016957.

11. Tavares, D.M.D.S., Bolina, A.F., Dias, F.A., Ferrei- ra, P.C.D.S., \& Santos, N.M.F. (2018). Overweight in rural elderly: association with health conditions and quality of life. Cien. Saude Colet, 23 (3), 913-922. doi: 10.1590/141381232018233.25492015.

12. Murad, M.H., Coto-Yglesias, F., \& Zumaeta-Garcia, M. (2011). A systematic review and meta-analysis of the treatments of varicose veins. J. Vasc. Surg., 53 (5), 49-65.

13. Hirokawa, M., Ogawa, T., Sugawara, H., Shokoku, S., \& Sato, S. (2015). Comparison of $1470 \mathrm{~nm}$ laser and radial 2ring fiber with $980 \mathrm{~nm}$ laser and bare-tip fiber in endovenous laser ablation of saphenous varicose veins: a multicenter, prospective, randomized, non-blind study. Ann. Vasc. Dis., 8 (4), 282-289. doi: 10.3400/avd.oa.15-00084.

14. Siribumrungwong, B., Noorit, P., \& Wilasrusmee, C. (2012). A systematic review and meta-analysis of randomised controlled trials comparing endovenous ablation and surgical intervention in patients with varicose vein. Eur. J. Vasc. Endovasc. Surg., 44, 214-223.

15. Biemans, A.A., Kockaert, M., Akkersdijk, G.P., van den Bos, R.R., de Maeseneer, M.G., Cuypers P., ..., \& Nijsten T. (2013). Comparing endovenous laser ablation, foam sclerotherapy, and conventional surgery for great saphenous varicose veins. J. Vasc. Surg., 58, 727-734.

16. Van der Velden, S.K., Pichot, O., \& van den Bos, R.R. (2015). Management strategies for patients with varicose veins (C2-C6): results of a worldwide survey. Eur. J. Vasc. Endovasc. Surg., 49, 213-220.

17. Samuel, N., Carradice, D., Wallace, T., Mekako, A., Hatfield, J., \& Chetter I. (2013). Randomized clinical trial of endovenous laser ablation versus conventional surgery for small saphenous varicose veins. Ann. Surg., 257, 419-426. doi: 10.1097/ SLA.0b013e318275f4e4.

18. Brittenden, J., Cotton, S.C., Elders, A., Ramsay, C.R., Norrie, J., Burr, J., ..., Campbell, M.K. (2014). A randomized trial comparing treatments for varicose veins. N. Engl. J. Med., 371, 1218-1227. doi: 10.1056/NEJMoa1400781.

19. Kaspar, S. (2016). Veins and diabetes. Vnitr. Lek., 56 (4), 329-332.

20. Antoniuk-Kysil, V.M., Dzubanovskyi, I.Ya., Yenikeeva, V.M., Lincher, S.I., Lypnyi, V.M., \& Zhulkevych, I.V. (2019). Planove khirurhichne likuvannia pervynnoho symptomnoho khronichnoho zakhvoriuvannia ven u vahitnykh [Planned surgical treatment of primary symptomatic chronic vein disease in pregnant women]. Aktualni pytannia pediatrii, akusherstva ta hinekolohii - Actual Problems of Pediatrics, Obstetrics and Gynecology, 1, 43-54 [in Ukrainian]. 


\section{THE WAYS OF OPTIMIZATION OF LASER AND CHEMICAL VEIN ABLATION IN VARICOSE VEIN DISEASE WITH COMORBID DIABETES MELLITUS}

The aim of the work: to assess the effectiveness of endovascular laser and chemical ablation in varicose vein disease (VVD) with type 2 comorbid diabetes mellitus (DM), develop the most optimal technology of therapeutic measures in this category of patients.

Materials and Methods. Under the survey there were 162 patients with VVD (19\% of men and $81 \%$ of women with the average age of 50 years) among whom the ratio of classes II, III, IV, V and VI of venous insufficiency was 1:1:3:1:2. DM occurred in $14 \%$ of the cases while the distribution of mild, moderate and severe forms of the disease was 1:2:4 and the distribution of the phases of compensation, subcompensation and decompensation was 1:4:6. The content of glucose, glycosylated hemoglobin, insulin, C-peptide, fructosamine and microelements associated with carbohydrate metabolism (chromium, manganese, selenium, zinc) was studied in the blood from the cubital vein and the affected vein of the lower extremities. Laser vein ablation was performed using the device "Photonika-LikaSurgeon" (Ukraine) and performing the paravasal "pillow" with Klein's solution using a pump for tuminascent anesthesia under ultrasound guidance and chemical (sclerotherapy) with a scleraine or fibrovascular solution. The first method was performed in 63 (39\%) patients, the second - in 99 (61\%).

Results and Discussion. The effectiveness of laser ablation depends on the class of venous insufficiency, previous phlebothrombosis, additional use of rivaroxaban and low-molecular-weight heparins in the complex of therapeutic measures, laser coagulation techniques, the presence and the severity of comorbid DM, the parameters of carbohydrate metabolism in the target vein besides the parameters of selenium and zincemia increase after the surgery, and the number of complications arising depends on the phase of DM and the level of chromium in the blood from a varicose vein. The results of sclerotherapy in women were better, the number of complications was less which depended on the level of venous insufficiency, previous phlebothrombosis and the lumen of the target vein of the leg, the parameters insulin, C-peptide and fructosamine in the blood from it. In a comparative assessment of various methods of surgical treatment of VVD laser ablation (coagulation) was characterized by a greater severity of comorbid DM, more frequent additional use of rivaroxaban and cyclo-3-fort, with the exception of patients with diabetic encephalopathy from the development, and sclerotherapy was not used in patients with nephropathy while the effectiveness of the activities carried out in both groups was about the same. In patients with VVD a therapeutic algorithm has been developed for applying the most optimal medical technology for laser and chemical ablation taking into account the nature of the flow of venous pathology and comorbid DM, systemic and local changes in carbohydrate metabolism, and background drug therapy.

Key words: veins; varicose veins; diabetes mellitus; treatment; vascular ablation.

П. Ф. ГЮЛЬМАМЕДОВ, Р. В. ПИЛИПЕНКО, О. В. СИНЯЧЕНКО, М. В. ЕРМОЛАЕВА, С. Н. ВЕРЗИЛОВ

Донецкий национальный медицинский университет, Лиман

\section{ПУТИ ОПТИМИЗАЦИИ ЛАЗЕРНОЙ И ХИМИЧЕСКОЙ АБ.ЛЯЦИИ ВЕН ПРИ ВАРИКОЗНОЙ БО.ЛЕЗИ С КОМОРБИДНЫМ САХАРНЫМ ДИАБЕТОМ}

Цель работы: оценить эффективность эндоваскулярной лазерной и химической абляции вен при варикозной болезни (ВБ) с коморбидным сахарным диабетом (СД) типа 2, разработать наиболее оптимальную технологию лечебных мероприятий у такой категории больных.

Материалы и методы. Под наблюдением находились 162 больных ВБ (19 \% мужчин и 81 \% женщин со средним возрастом 50 лет), среди которых соотношение II, III, IV, V и VI классов венозной недостаточности составило 1:1:3:1:2. СД имел место в 14 \% случаев, при этом распределение легкой, средней тяжести и тяжелой формы болезни составило 1:2:4, а фаз компенсации, субкомпенсации и декомпенсации - 1:4:6. В крови из локтевой вены и пораженной вены нижних конечностей изучено содержание показателей глюкозы, гликозилированного гемоглобина, инсулина, С-пептида, фруктозамина и ассоциированных с углеводным метаболизмом микроэлементов (хрома, марганца, селена, цинка). Лазерную абляцию вен осуществляли с помощью аппарата “Фотоніка-Ліка-Хірург” (Украина) и выполнения паравазальной “подушки” раствором Кляйна при помощи помпы для туминесцентной анестезии под ультразвуковым контролем, а химическую (склеротерапию) - раствором склеровейна или фибровейна. Первый метод выполнен 63 (39 \%) больным, второй - 99 (61%).

Результаты исследований и их обсуждение. Эффективность лазерной аблации зависит от класса венозной недосточности, перенесенного в прошлом флеботромбоза, дополнительного использования в комплексе лечебных мероприятий ривароксабана и низкомолекулярных гепаринов, методики проводимой лазерной коагуляции, наличия и тяжести течения коморбидного СД, показателей углеводного обмена в целевой вене, причем после хирургического вмешательства возрастают параметры селен- и цинкемии, а число возникших осложнений зависит от фазы СД и уровня хрома в крови из варикозно расширенной вены. Результаты склеротерапии у женщин были лучше, число осложнений меньше, которые зависели от уровня венозной недостаточности, перенесенного в прошлом флеботромбоза и просвета целевой вены голени, параметров в крови из нее инсулина, C-пептида и фруктозамина. При сравнительной оценке разных методов хирургического лечения ВБ, лазерная абляция (коагуляция) отличалась большей тяжестью течения коморбидного СД, более частым дополнительным использованием ривароксабана и цикло-3-форта, исключением из разработки больных с диабетической энцефалопатией, а склеротерапия не была использована у пациентов с нефропатией, при этом эффективность выполненных мероприятий в обеих группах оказалась примерно одинаковой. У больных ВБ разработан лечебный алгоритм применения наиболее оптимальной медицинской технологии лазерной и химической абляции с учетом характера течения венозной патологии и коморбидного СД, системных и локальных изменений углеводного метаболизма, фоновой медикаментозной терапии.

Ключевые слова: вены; варикоз; сахарный диабет; лечение; абляция сосудов. 